\title{
PENGEMBANGAN PENDIDIKAN NON FORMAL MELALUI PROGRAM KEAKSARAAN FUNGSIONAL PUSAT KEGIATAN BELAJAR MASYARAKAT
}

\author{
Oleh : \\ Endah Puspa Pratiwi, \& Budhi Wibhawa \\ Email: \\ (endahpuspap@gmail.com; budhiwibhawa@gmail.com)
}

\begin{abstract}
ABSTRAK
Pendidikan menjadi salah satu aspek yang cukup memegang peranan penting di masyarakat, dengan di satu sisi pendidikan mengalami problem yang semakin meningkat, membangun suatu komunitas dalam menciptakan perubahan yang diharapkan menjadi satu langkah yang harus terus dilakukan (keberlanjutan), peran stakeholder dibutuhkan dalam setiap proses pendidikan. Salah satunya dapat melalui program keaksaraan fungsional, program ini mempunyai tujuan menciptakan kesempatan bagi masyarakat untuk dapat mengenyam pendidikan tanpa harus mengelurkan biaya yang lebih tinggi. Pengembangan pendidikan non formal ini pada dasarnya merupakan sarana substansial untuk membantu masyarakat yang mengalami buta aksara supaya dapat mengenal angka dan huruf tanpa terhalang oleh biaya, tempat, usia, dan lain sebagainya. Ditambah degan ada sekitar 300.000 - 400.000 anak yang potensial buta aksara akibat putus sekolah di kelas 1-3 SD. Sehingga tingginya masalah buta aksara pada penduduk usia produktif dan usia sekolah perlu penanganan secara khusus. Dalam program ini pendekatan yang dilakukan menggunakan pendekatan partisipatif dengan prinsip bahwa setiap individu berhak mendapatkan pendidikan, tidak terkecuali bagi mereka yang mengalami buta aksara.
\end{abstract}

Kata kunci: pendidikan non formal, keaksaraan fungsional, PKBM

\section{PENDAHULUAN}

Pendidikan memiliki peranan strategis dalam menyiapkan generasi berkualitas, sebagai institusi utama dalam upaya pembentuk sumber daya manusia (SDM) yang kompeten, pendidikan menjadi taken for granted terkait dengan eksistensi suatu bangsa. Dengan perkembangan jaman dan teknologi yang semakin pesat menuntut individu untuk dapat beradaptasi dengan setiap perubahan yang terjadi.Di era globalisasi seperti ini, keterampilan dan keahlian menjadi dasar utama yang dapat mengantarkan seseorang menjadi individu yang dapat beradaptasi dengan lebih baik. Banyak cara yang dapat dilakukan untuk mendapatkan keterampilan atau keahlian tersebut, salah satunya melalui pendidikan. Berdasarkan Undang-Undang Sistem Pendidikan Nasional (UU Sisdiknas) Nomor 20 Tahun 2003, pendidikan adalah usaha sadar dan terencana untuk mewujudkan suasana belajar dan proses pembelajaran agar peserta didik secara aktif mengembangkan potensi dirinya untuk memiliki kekuatan spiritual keagamaan, pengendalian diri, kepribadian, kecerdasan, akhlak mulia, serta keterampilan yang diperlukan dirinya, masyarakat, bangsa, dan negara.

Hakekatnya manusia sebagai makhluk sosial membutuhkan lingkungan hidup berkelompok untuk mengembangkan dirinya, serta mempunyai potensi-potensi yang dapat dikembangkan dan memiliki kebutuhan yang harus dipenuhi (materi dan spiritual). Proses belajar menjadi satu fase 
penting yang dilalui oleh setiap individu tidak terlepas dari motivasi apa yang melatarbelakanginya untuk mau belajar. Supaya siap dalam menghadapi setiap perubahan yang terjadi.(Bigge and Hunt, 1969, p.260). Oleh sebab itu, pendidikan sebagai suatu subsistem memegang peranan penting dalam membangun kualitas masyarakat kearah yang lebih baik.

Namun pada praktiknya, pendidikan yang terjadi di masyarakatmengalami banyak hambatan dan tantangan tersendiri yang sangat memprihatinkan. Mahalnya biaya pendidikan yang tidak serta merta dibarengi dengan peningkatan kualitas secara signifikan, tentu menimbulkan tanda tanya besar mengenai orientasi pendidikan yang sebenarnya sedang ingin dicapai.Menurut Syafaruddin anzizhan dalam bukunya yang berjudul sistem pengambilan keputusan pendidikan menyatakan bahwa problem dunia pendidikan khususnya yang ada di sekolah semakin kompleks dari tahun ke tahun masih banyak masyarakat yang putus sekolah, tinggal kelas, motivasi belajar rendah, kemampuan menerima pelajaran lemah, dan prestasi tak dapat dibanggakan. Hal tersebut disebabkan oleh berbagai faktor, misalnya keterbatasan biaya, sulitnya akses pendidikan, hingga pergaulan dan budaya yang masih tertanam kuat di masyarakat (faktor lingkungan).

\section{PEMBAHASAN}

Isu pendidikan telah menjadi salah satu permasalahan serius yang harus segera mendapat perhatian dan penangganan yang optimal dari semua kalangan masyarakat.Banyak faktor yang menyebabkan sistem pendidikan tidak berjalan secara maksimal.Menurut Muhammad Firman (2009), faktor ketidakmampuan membiayai sekolah ataufaktor ekonomi menjadi faktor penyebab paling dominan putus sekolah. Kenyataanitu dibuktikan dengan tingginya angka rakyat miskin di Indonesia yang anaknyatidak bersekolah atau putus sekolah berasal dari aspek internalnya, yaitu tidak adakeinginan atau motivasi untuk melanjutkan sekolah dalam diri anak sehinggamenyebabkannya memutuskan untuk berhenti sekolah. Burhannudin (dalam Prihatin, 2011), menyatakan bahwa setidaknya ada enam faktor yang menyebabkan terjadinya putus sekolah khususnya pada jenjang pendidikan dasar yaitu faktor ekonomi, minat untuk bersekolah rendah, perhatian orang tua yang kurang, fasilitas belajar yang kurang mendukung, faktor budaya dan lokasi atau jarak sekolah. Berdasarkan hasil penelitian yang dilakukan oleh Prihatin Pebriana denganjudul skripsi Faktor-Faktor Putus Sekolah Usia Pendidikan Dasar (7-15 Tahun) di Kecamatan Labuhan Haji Kabupaten Lombok Timur tahun 2011. Hasil penelitiannya menunjukkan bahwa ditemukan penyebab anak putus sekolah dari faktor ekonomi keluarga dan perhatian orang tua. Dari faktor ekonomi keluarga antara lain kondisi ekonomi keluarga yang lemah mengakibatkan terbatasnya kemampuan memenuhi kebutuhan hidup termasuk pendidikan. (Prihatin Pebriana, 2011).

Hal tersebut juga didukungoleh penelitian yang dilakukanoleh Ni Ayu Krisna Dewi1, Anjuman Zukhri1, I Ketut Dunia2 (2014) mengenai analisis faktor penyebab anak putus sekolah di Kecamatan Gerokgak Tahun 2012/2013 menjelaskan bahwa faktor yang menyebabkan anak putus sekolah diantaranya:

1. faktor ekonomi merupakan faktor pertama penyebab anak putus sekolah. Ketidakmampuan keluarga si anak untuk membiayai segala proses yang dibutuhkan selama menempuh pendidikan atau sekolah dalam satu jenjangtertentu, walaupun pemerintah telah mencanangkan Program Pendidikan Gratis dua belas tahun, namun belum berimplikasi secara maksimal terhadap penurunan jumlah anak putus sekolah.

2. Kurang perhatian orang tua, rendahnya perhatian orang tua terhadap anak dapat disebabkan karena kondisi ekonomi keluarga atau rendahnya pendapatan orang tua si anak sehingga perhatian orang tua lebih banyak tercurah pada upaya untuk memenuhi kebutuhan keluarga.

3. Fasilitas pembelajaran yang kurang memadai merupakan faktor ketiga. fasilitas belajar yang tersedia di sekolah, misalnya perangkat (alat, bahan, dan media) pembelajaran yang kurang memadai, buku pelajaran kurang memadai, dan sebagainya. Kebutuhan dan fasilitas belajar 
yang dibutuhkan siswa tidak dapat dipenuhi siswa dapat menyebabkan turunnya minat anak yang pada akhirnya menyebabkan putus sekolah.

4. Rendahnya minat bersekolah, minat yang kurang dapat disebabkan oleh pengaruh lingkungan misalnya tingkat pendidikan masyarakat rendah yang diikuti oleh rendahnya kesadaran tentang pentingnya pendidikan. Ketidakmampuan ekonomi keluarga dalam menopang biaya pendidikan yang berdampak terhadap masalah psikologi anak sehingga anak tidak bisabersosialisasi dengan baik dalam pergaulan dengan teman .

5. Budaya merupakan faktor kelima yang terkait dengan kebiasaan masyarakat di sekitarnya. Rendahnya kesadaran orang tua atau masyarakat akan pentingnya pendidikan. Perilaku masyarakat pedesaan dalam menyekolahkan anaknya lebih banyak dipengaruhi faktor lingkungan. Mereka beranggapan tanpa bersekolahpun anak mereka dapat hidup layak seperti anak lainnya yang bersekolah, oleh karenadi desa jumlah anak yang bersekolah lebih banyak dan mereka dapat hidup layakmaka kondisi seperti itu dijadikan landasan dalam menentukan masa depan anaknya. Pandangan banyak anak banyak rejeki membuat masyarakat di pedesaan lebih banyak mengarahkan anaknya yang masih usia sekolah diarahkan untuk membantu orang tua dalam mencari nafkah.

6. Lokasi atau letak sekolah merupakan faktor keenam yang mampu menyebabkan anak putus sekolah. Jarak yang jauh dengan akses yang sulit merupakan hal-hal yang harus dipertimbangkan oleh masyarakat untuk bisa menyekolahkan anak-anaknya. Alat transportasi yang kurang serta jarak antara rumah dengan sekolah yang cukup jauh. Selain itu juga dengan akses yang dirasa sulit, keselamatan pun dianggap tidak terjamin.

Baharuddin M (1982:320) juga mengatakan: "Nampaknya di negara kita faktor dana merupakan penghambat utama, untuk mengejar ketinggalan kita dalam dunia pendidikan. Sudah tidak dapat dipungkiri bahwa tanpa dana yang cukup, tidak akan dapat diharapkan pendidikan yang sempurna. Selain faktor ekonomi, sarana dan prasaran sekolah juga ikut menentukan seseorang mengalami putus sekolah. Baharuddin M (1982:320) mengemukakan bahwa: Apabila faktor sarana tidak terpenuhi, maka banyak murid usia sekolah, maupun berbagi tingkat pendidikan yang tidak bisa bersekolah, atau tidak bisa melanjutkan sekolahnya. Bila hal tersebut terjadi berarti "putus sekolah" pun terciptalah dikarenakan faktor tersebut. yang vital adalah kurangnya pengadaan sarana tempat belajar dan pengadaan guru. Lingkungan dan masyarakat juga tidak terlepas menjadu faktor penyebab seseorang mengalami putus sekolah.

A.H. Harahap (1981:143)juga menyatakanbahwalingkungan masyarakat merupakan faktor yang cukup kuat dalam mempengaruhi perkembangan anak remaja yang sulit dikontrol pengaruhnya. Orang tua dan sekolah adalah lembaga yang khusus, mempunyai anggota tertentu, serta mempunyai tujuan dan tanggung jawab yang pasti dalam mendidik anak.Berbeda dengan masyarakat, di mana di dalamnya terdapat berbagai macam kegiatan.Berlaku untuk segala tingkatan umur dan ruang lingkup yang sangat luas.

Mencari dan menemukan solusi dari semua permasalahan pendidikan diatas tidaklah sepraktis dan semudahyang dibayangkan, melakukan suatu perubahan membutuhkan koordinasi dan kerjasama yang berkesinambungan antara semua pihak. Salah satunya yaitu masyarakat, masyarakat yang transparan adalah masyarakat yang anggotanya langsung berpartisipasi di dalam pembangunan. Penyelenggaraan pendidikan harus mengikutsertakan masyarakat. Oleh sebab itu, masyarakatlah yang menjadistake-holders pertama dan utama dari proses pendidikan tersebut. Menurut M. Sobry Sutikno dalam bukunya yang berjudul pendidikan sekarang dan masa depan: pemberdayaan dalam upaya mengelola pendidikan merupakan salah satu perwujudan dari demokratisasi pendidikan. Tidak mengherankan dewasa ini, muncul suatu gerakan yang bernama community-based education, community-based education merupakan dasar dari pembangunan suatu masyarakat yang demokratis (Edward B. Fiske, 1998:26). 
Untuk mengatasi persoalan di atas pendidikan non formal menjadi suatu alternatif solusi tersendiri.PNF juga menjadi salah satu upaya dalam perluasaan dan peningkatan mutu layanan pendidikan bagi masyarakat.Coombs (Trisnamansyah, 2003: 19) mendefinisikan nonformal education sebagai setiap kegiatan pendidikan yang diorganisasikan di luar sistem persekolahan yang mapan baik dilakukan secara terpisah atau sebagai bagian penting dari kegiatan yang lebih besar, dilakukan secara sengaja untuk melayani peserta didik tertentu guna mencapai tujuan belajarnya.Berbeda dengan pendapat dari Sudjana (2000: 63) yang menyatakan bahwa pendidikan luar sekolah telah hadir di dunia ini sama tuanya dengan kehadiran manusia yang berinteraksi dengan lingkungan di muka bumi ini dimana situasi pendidikan ini muncul dalam kehidupan kelompok dan masyarakat. Kegiatan pendidikan dalam kelompok dan masyarakat telah dilakukan oleh umat manusia jauh sebelum pendidikan sekolah lahir di dalam kehidupan masyarakat.Pada waktu permulaan kehadirannya, pendidikan luar sekolah dipengaruhi oleh pendidikan informal, yaitu kegiatan yang terutama berlangsung dalam keluarga dimana terjadi interaksi di dalamnya berupa transmisi pengetahuan, keterampilan, sikap, nilai, dan kebiasaan. Artinya pendidikan memiliki peran dan fungsi yang sangat kuat terhadap kehidupan masyarakat, jauh sebelum masyarakat menyadari akan pentingnya sebuah pendidikan itu sendiri.

Salah satu pengembangan pendidikan yang berbasis masyarakat (community-based education) yaitu Pusat Kegiatan Belajar Masyarakat (PKBM) yang telah dibentuk dan dilegalisasi keberadaannya dalam UU Sisdiknas No. 20 Tahun 2003, pasal 26 ayat 4.Dalam upaya meningkatkan dan menjamin mutu pendidikan khususnya pendidikan non formal, lembaga ini telah diakreditasi sejak Tahun 2010 oleh Badan Akreditasi Nasional Pendidikan Non Formal (BAN-PNF).Programprogram yang diselenggarakan di PKBM sangat beragam dan tidak terbatas. Namun, harus sesuai dengan kondisi, potensi dan kebutuhan masyarakat di mana PKBM itu berada atau dikatakan relevan dengan suatu kondisi masyarakat PKBM itu berada (http://pkbm-Indonesia.com/pkbm).

Menurut Mustofa kamil dalam bukunya yang berjudul Pendidikan Non Formal: Pengembangan melalui PKBM: Pendidikan non-formal sebagai bagian dari system pendidikan memiliki tugas sama dengan pendidikan lainnya (pendidikan formal) yakni memberikan pelayanan terbaik terhadap masyarakat terutama masyarakat sasaran pendidikan non-formal. Sasaran pendidikan non-formal yang semakin luas yang tidak hanya sekedar berhubungan dengan masyarakat miskin dan bodoh (terbelakang, buta pendidikan dasar, drop out pendidikan formal), akan tetapi sasaran pendidikan non-formal terus meluas maju sesuai dengan perkembangan ilmu pengetahuan dan teknologi sertaperkembangan lapangan kerja dan budaya masyarakat itu sendiri. Mengingat sasaran tersebut, maka program/kegiatan pendidikan non-formal harus terus diperluas sesuai dengan kebutuhan dan kondisi perkembangan masyarakat.

Menurut salah satu data dari PKBM Riau menunjukkan bahwa rata-rata lama pendidikan penduduk usia 15 tahun hanya 7,1\% dibawah pendidikan dasar 9 tahun. Angka partisipasi sekolah penduduk usia SD (7-12 tahun) 96\%, usia SMP (13-15 tahun) 81\% dan SMA (16-18 tahun) 50,97 \% . Angka partisipasi sekolah ini, menunjukkan bahwa semakin tinggi jenjang pendidikan jumlah penduduk yang tidak dapat meneruskan semakin tinggi pula.Di sisi lain pertumbuhan ekonomi mencapai 5,4 \%, kondisi ekonomi nasional masil labil, dunia usaha belum normal, pertumbuhan angkatan kerja berkisar 2,3 - 2,75 juta orang, pemutusan hubungan kerja terjadi, dan daya beli masyarakat turun terus. Kondisi ini akan berakibat langsung dengan ketidakmampuan masyarakat untuk menyekolahkan anak-anaknya dan sebagian besar dari mereka tinggal di daerah pedesaan, dengan sarana infrastruktur yang ada sangat minim sehingga tidak mendukung untuk pemberdayaan kemampuan sosial dan ekonominya. Tentu banyak faktor yang menyebabkannya, fakta menunjukkan bahwa karena kemiskinan dan kondisi daerah menjadi penyebab permasalahan.

Krisis yang terjadi khususnya krisis ekonomi langsung mempengaruhi peta pendidikan dan kondisi sosial masyarakat. Angka putus sekolah meningkat, lapangan kerja semakin langka, dan jumlah pengangguran bertambah, sehingga putaran kemiskinan kembali terjadi yang menyebabkan 
kualitas pendidikan penduduk rendah, sehingga produktivitas masyarakat juga akan rendah. Masih tingginya buta aksara pada penduduk usia produktif dan usia sekolah perlu penanganan secara khusus. Secara keseluruhan tercatat sebanyak 18,7 juta penduduk buta aksara, dan dari jumlah btersebut sebesar 5,2 juta adalah penduduk usia produktif. Ditambah lagi diperkirakan ada sekitar 300.000 400.000 anak yang potensial buta aksara akibat putus sekolah di kelas 1-3 SD, dan sekitar 3 juta anak yang tidak tertampung atau mampu melanjutkan ke jenjang pendidikan di SMP/MTs.

Dalam bukunya Mustofa Kamil juga menjelaskan salah satu program yang ada di PKBM yaitu program keaksaraan fungsional, program ini bertujuan membelajarkan masyarakat (warga belajar) agar dapat memanfaatkan kemampuan dasar baca, tulis, hitung dan kemampuan fungsionalnya dalam kehidupan sehari-hari. Program keaksaraan diselenggarakan secara massal dengan melibatkan berbagai masyarakat dan pemerintah yang memiliki tanggung jawab dalam pembebasan buta aksara.Kesadaran ini didasarkan pada tanggung jawab dalam pembebasan buta aksara dan atas pandangan bahwa terdapat hubungan antara kebuta aksaraan dengan kemiskinan. Program Keaksaraan Fungsional adalah sebuah usaha pendidikan luar sekolah dalam membelajarkan warga masyarakat penyandang buta aksara agar mampu menulis, membaca dan berhitung untuk tujuan yang pada kehidupan sehari-hari dengan memanfaatkan potensi sumber daya yang ada di lingkungan sekitarnya, untuk peningkatan mutu dan taraf hidupnya. Program keaksaraan mempunyai dua tahapan yang pertama adalah tahap keaksaraan dasar dan tahap keaksaraan mandiri.Tahap keaksaraan dasar adalah warga belajar yang belum memiliki pengetahuan dasar tentang calistung (baca tulis hitung) tetapi telah memiliki pengalaman yang dapat dijadikan kegiatan pembelajaran.Yang kedua adalah tahap keaksaraan mandiri pada tahap ini warga belajar telah memiliki pengetahuan dan pengalaman yang selanjutkan diarahkan kepada tahap kemandirian.

\section{KESIMPULAN}

Perubahan jaman yang semakin canggih membuat individu untuk dapat beradaptasi dengan setiap perubahan.Pendidikan sebagai suatu subsistem yang cukup memegang peranan penting dalam mensejahterakan kehidupan bangsa, saat ini dianggap mengalami banyak kegagalan dari setiap sistem dan prakteknya.Hal tersebut terlihat dari masih tingginya angka putus sekolah yang dialami oleh masyarakat sehingga berpotensi mengalami buta aksara.

Banyak faktor yang menyebabkan terjadinya hal tersebut, diantaranya faktor ekonomi keluarga, fasilitas pendidikan yang kurang, minat belajar rendah, perhatian orang tua, pasrtisipasi masyarakat yang menurun,hingga akses pendidikan yang masih sulit didapat oleh sebagian masyarakat.Pendidikan formal dianggap belum cukup memainkan peranya dalam mengatasi setiap permasalahan tersebut.Hingga munculnya kesadaran masyarakat akan pentingnya mengelola pendidikan di laur lingkup pendidikan formal membuat suatu kondisi baru yang diharapkan dapat membantu menyelesaikan fenomena tersebut.

Bagaimanapun, masyarakat yang mengalami buta aksara tetap memiliki hak untuk dapat mengembangan setiap kemampuan dan potensinya terlepas dari hambatan yang dihadapi seperti batas usia dan financial. Cara lain dalam pembaharuan pendidikan yaitu melalui pengembangan pendidikan masyarakat lokal yang berbasis masyarakat (school-based education) melalui pembentukan Program keaksaraan Pusat Kegiatan Belajar Masyarakat (PKBM) membelajarkan warga masyarakat penyandang buta aksara agar mampu menulis, membaca dan berhitung untuk tujuan yang pada kehidupan sehari-hari dengan memanfaatkan potensi sumber daya yang ada di lingkungan sekitarnya, untuk peningkatan mutu dan taraf hidupnya.

\section{DAFTAR PUSTAKA}

Buku

Hamalik, Oemar (1989). Metodologi Pengajaran Ilmu Pendidikan. Bandung: Penerbit Mandar Maju 
Harahap, A.H (1981). Bina Remaja. Medan: Yayasan Bina Pembangunan Indonesia

Kamil, Mustofa (2009). Pendidikan Non Formal Pengembangan melalui PKBM.Bandung: Penerbit Alfabeta

M, Baharuddin (1982). Putus Sekolah dan Masalah Penanggulangannya. Jakarta: Yayasan Kesejahteraan Keluarga Pemuda 66

Prof. Dr. H.A.R Tilaar, M.Sc. Ed (1999). Pendidikan Kebudayaan dan Masyarakat Madani Indonesia Strategi Reformasi Pendidikan Nasional.Bandung: Penerbit PT Remaja Rosdakarya

Sutikno, M. Sobry (2006). Pendidikan Sekarang dan Masa Depan Suatu Refleksi untuk Mewujudkan Pendidikan yang Bermakna.Mataram-Lombok: Penerbit NTP PRESS

Sudjana, D. (2000). Pendidikan Luar Sekolah. Wawasan, Sejarah Perkembangan, Falasafah, Teori Pendukung, Asas. Bandung: Penerbit Falah Production.

Trisnamansyah, Sutaryat. (2003). Materi Pokok Perkuliahan Filsafat, Teori, dan Konsep Dasar PLS. Bandung: Makalah tidak diterbitkan

Sumber lain

Burhannudin (2008).Penetaan Anak Tidak dan putus Sekolah di Kota Mataram dan Kabupaten Sumbawa Besar Usia 5-12 Tahun. http://www.puslitjaknov. org/data/file/2008/ makalah_peserta/30_Burhanudin_Pemetaan.pdf/. Diakses pada tanggal 14 Desember 2014 pukul 17.34 WIB

Dewi, Ni Ayu Krisna dkk., (2004). Analisis Faktos-faktor Penyebab Anak Putus Sekolah Usia Pendidikan Dasar di Kecamatan Gerokgat Tahun 2012/201. Vol 4 . No 1. http://ejournal.undiksha.ac.id/index.php/JJPE/article/viewFile/1898/1650. Diakses pada tanggal 13 Desember 2014 pukul 19.33 WIB

Firma, Muhammad (2009). Problem Putus Sekolah yang Kompleks. http://kosmo.vivanews.com/news/read/70884problem_putus_sekolah_yang_kompleks .Diakses pada tanggal 14 Desember 2014 pukul 17.44 WIB

PKBM Pelita riau (2012).Pkbm Solusi Pendidikan Memberdayakan Masyarakat Marginal.http://pkbmpelitariau.wordpress.com/artikel/ . 14 Desember 2014 pukul 19.53 WIB 